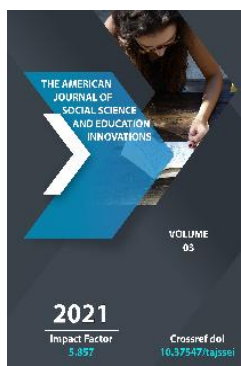

\title{
The Labor Heroism Of The People Of Uzbekistan Behind The Front During The Second World War
}

\author{
Naim Khalimovich Oblomurodov \\ Professor, Doctor of Historical Sciences, Tashkent Institute of Finance, Uzbekistan
}

Journal Website:

http://theamericanjour

nals.com/index.php/taj

ssei

Copyright: Original content from this work may be used under the terms of the creative commons attributes

\section{ABSTRACT}

The article highlights the heroism of the Uzbek people and Uzbeks during the Second World War, which is one of the examples of patriotism, providing national support to the front and the front defense fund, their contribution to the victory in the war with their hard work. In other words, the active participation of Uzbeks in the movement to establish a defense fund from the first days of the war, the economic and social characteristics of the material assistance provided by Hitler's Germany to the occupied territories, including Russia, Ukraine and Belarus. In particular, it analyzes the humanitarian contribution of Uzbek workers to the defense fund behind the front line, part of their salaries, money earned on "communist Saturdays", personal funds of citizens, valuables, government bonds, goods, especially agricultural workers of the republic and the herdsmen handed over food and livestock to the warriors and delivered them to the battlefields, as well as their unparalleled heroism in ending the war with victory.

\section{KEYWORDS}

Uzbekistan, World War II, heroism, courage, front, Germany, hitlerites, nazis, fund, workers, products, industry, products, agriculture, livestock, food, city, village, township, population, men, women. 


\section{INTRODUCTION}

\section{Method and methodology:}

The article is based on the principles of objectivity, consistency, chronological study of historical and social events, reliance on sources and evidence, and their validity, accepted in all social sciences and humanities. The article is based on content analysis, historical-comparative analysis, observation and experimental observation methods of some sources. The issues raised in the article are based on the principles of humanity, based on the courage and heroism of the Uzbek people during the Second World War. The results of research based on such an approach, especially the support of the people to the front and the front defense fund during the war years, serve to positively change people's lifestyles today, increase the worldview of young people, develop their labor and military patriotism. Any scientific article or research is reliable and rich in evidence only when it is studied theoretically and methodologically. Therefore, this article is based on historical sources specific to the science of history, based on the methods of their expert analysis

\section{CONCLUSIONS AND DISCUSSIONS}

If we look at the historical evidence, during the Second World War, the Nazis destroyed 1,710 towns and townships in the former Soviet Union, 70,000 villages, and 3,185 industrial enterprises employing about 4 million people. Only in Russia, 500 cities, 14,000 villages, enterprises worth 18 billion soums were destroyed per year, and about 3 million people were tortured and deported to
Germany. The damage to the Ukrainian economy amounted to 235 billion soums, where the German Nazis destroyed 714 cities and working-class settlements and destroyed 16,000 manufacturing enterprises. In Belarus, 209 towns, 9,200 villages and 10,000 industrial enterprises were destroyed, causing 75 billion soums of damage to the country's economy. About 2 million people were killed and 380,000 were tortured, some of whom were taken to Germany for destruction and exploitation [1.39-42].

In 1941, the total population of Uzbekistan was $6,551,000$, of which about 1.5 million were believed to have taken part in the war. According to new data, about 1 million 951 thousand people from Uzbekistan were mobilized for the war [2. № 80.]. By the end of 1941, about 300 enterprises were put under military control, reconstructed to produce military equipment, weapons and ammunition. In these enterprises, the men mobilized to the front were replaced by the elderly aged and women. Work had begun on the relocation of important industrial enterprises from the war-torn and enemyprone areas to the East, including Uzbekistan, on the property of collective farms, state farms and machine-tractor stations (MTS), as well as on cultural property and educational institutions. Residents of towns and villages burned and destroyed by the Nazis, their fathers, the children of those who perished from the first days of the war, hundreds of thousands of people began to migrate in large numbers. 
As another proof and symbol of true humanity and perseverance during the war years, Zulfiya Aya lived in the village of Khanabad, Zangiota district, Tashkent region. After the death of her husband Holmat aka, she raised 5 sons and 1 daughter alone. When her children were grown up the war broke out and she had also sent his 5 young sons to the front. Zulfiya aya Zokirova's five sons, Isaqjon, Ahmadjon, Mahamadjon, Vahobjon, Yusufjon, went to war, but none of them returned from the front. Aya's 4 daughters-in-law and five grandchildren were orphaned. Until the end of her life, the mother lived with the memory of the heroic sons, the lives of his daughters-inlaw, grandchildren, the worries and joys of the land. Zulfiya aya's loving daughters-in-law followed her example and helped her, all remained faithful to their husbands and families, never married again. They experienced all the mental hardships for a lifetime [3. № 80].

Large losses during the war years had a particularly strong impact on industries, agriculture, and other sectors. Thousands of people, industrial enterprises, educational institutions, scientific organizations and other material resources were relocated from the front lines. 104 of them were relocated to Uzbekistan. These included the Leningrad Textile Machinery Plant, Krasny-Aksoy, Rosselmash, Sumy Compressor and Dnepropetrovsk Carborundum Plants, Moscow's Elektrokabel and Podiyomnik Plants, Chkalov Aircraft Plant, Krasny Put Plant, and Kiev's Transsignal Plant, Stalingrad Chemical Plant and many other enterprises. 55 of them were located in Tashkent and Tashkent region, 14 in Samarkand, 22 in the Fergana Valley, and two in Bukhara region. The relocated plants and factories were put into operation in a short period of time, i.e. 25 days after Rosselmash, and 29 days after the arrival of Krasny Aksoy plant. By December 1941, about 50 of the evacuated enterprises were put into operation. In the first half of 1942, all the listed industrial enterprises began to produce [4.77-79].

As a result of the construction and commissioning of 280 new enterprises in the country during the war, by 1945 , industrial production had almost doubled compared to the pre-war period, oil production 4, metal production 4.8, machine building 13.4 times, coal production 30, energy production increased 2.42 times.

As a result of the selfless work of the railways of Uzbekistan in 1941-1942, 17.5 thousand wagons loaded with equipment of industrial enterprises were transported. The railway network, which served as the main means of communication between the rear and the front, doubled in 1941-1945. The motor vehicle also played an important role as a means of transportation and communication during the war years. In 1945, the volume of cargo transported by road in the republic doubled compared to 1940.

In such a difficult situation, in accordance with strategic plans, it was possible to send the necessary weapons, ammunition and food to the front and behind it. All the peoples of the Union assisted the liberated districts of the farms destroyed by the war from the invaders. All Soviet republics, including Uzbekistan, took part in the reconstruction of the national economy of the liberated districts. Forms of this assistance were different districts. Many volunteers, mostly young people, went to the destroyed cities to take part in the restoration 
work to restore the destroyed farm. The main thing was that agricultural specialists were sent to the front, grain, cattle, tractors, combines, cars and many other things were sent. The war strengthened the friendship of the peoples of the Union, and the calamity that befell all brought the people closer together.

On behalf of the Central Committee of the AllUnion Communist Party and the State Defense Committee, the Union State Planning Department developed a military "Economic Plan" for the 4th quarter of 1941 and 1942, which was approved by the Politburo on August 16, 1941 [5. 181]. The plan outlined a broad program for the construction of new plants, mines, and mines in the eastern regions of the Union, including Uzbekistan, as well as for the production of weapons and ammunition, especially many tanks and artillery pieces. Uzbeks took an active part in the nationwide movement to establish a fund for the production of defense and military equipment [6.77-79].

All citizens were able to transfer their earnings to the active army, the front troops, and most of them to the "Front Defense Fund", along with taxes paid on the income from their farms and personal farms. Despite the difficult conditions in the country, the people of the republic voluntarily donated their hard-earned money to this fund in cash.

Also, a fraternal aid fund was established in the republic for the occupied territories and liberated areas. During the war, labor collectives and individual citizens donated one- or two-day wages to the defense fund, handing out valuables, bonds, and cash. Saturdays and Sundays were held everywhere, and the money earned there was also donated to the defense fund.

For example, workers of the republic donated more than 650 million soums to the National Defense Fund in the form of cash and government bonds, about $55 \mathrm{~kg}$ of precious metals. These funds were used to produce armored trains, air squadrons, tank columns and other equipment named "Uzbekistan", "Krasnovostochnik", "Komsomol of Uzbekistan", and sent them to the front [7. 245].

The assistance provided by the workers of the republic to the front strengthened the armament of the combat units with equipment, raised the morale of the Soviet troops, and increased their strength and power in the fight against the enemy. A letter from the army under Lieutenant General Panfilov to the Central Committee of the Communist Party of Uzbekistan testified to the fact that the soldiers and officers who fought in the tanks named "20 years of Soviet Uzbekistan" cared about the Red Army and provided with excellent armored vehicles. The Soviet Union expresses its deep gratitude to the workers of Uzbekistan "[8.245].

In particular, in addition to the payment of taxes imposed by the state, the workers of Uzbekistan constantly sent greetings to the soldiers of the Red Army. The soldiers of the South-Western Front wrote in one of the letters: "The gifts brought by the delegation and the presence of this delegation among us evoked a deep and sincere gratitude in every soldier and commander ..." We are grateful to the workers, collective farmers and intellectuals of sunny Uzbekistan. We are 
happy, "the congratulatory message reads [ 9 . 245].

The resolution adopted by the Tashkent regional party meeting in the Supreme Soviet of the Uzbek SSR on October 20, 1941, called on the Tashkent communists to mobilize for the selfless fulfillment of the sacred patriotic duty before them " to double or even triple their efforts to provide more financial assistance to the front, to strengthen revolutionary cohesion and unity".[10. 245].

R. Duschanov argues that from the first years of the war, the Defense Fund was also established in all branches of the State Bank of the former Soviet Union. The people also handed over their valuables and money to this bank. In the pre-war years, taxes were levied on the population, while during the war years, the local population voluntarily brought in the funds. During the war, the Defense Fund received \$ 17.6 billion. rub cash, $13.2 \mathrm{~kg}$. platinum, $131.4 \mathrm{~kg}$ gold, $9,519 \mathrm{~kg}$. silver, jewelry worth 1.7 billion rubles [11. 299-300]. In order to establish a defense fund in Uzbekistan from the first days of the war, workers, collective farmers and intellectuals donated one day's wages, money from communist sabbaticals, personal savings, valuables, government bonds, goods and foodstuffs..

According to the author, in the first days of the war, only from the population of the republic was 30 million. rubles, bonds and valuables were gathered. The population of Uzbekistan contributed to the Defense Fund during the war a total of 649.9 million rubles in cash, $22 \mathrm{~kg}$ of gold and silver.
In general, the taxes levied on the population for the Defense Fund and the Red Army Fund in the country had been constantly changing and increasing. During the war years, taxes on the population increased 4.2 times. In 19411945, the budget received 111.7 billion. rubles were invested. In addition, money was transferred to the budget through government bonds. Government bonds increase by 113.9 billion rubles, which accounted for 10.2 percent of budget revenues during the war. Taxes from public institutions increased by 21.4 percent during the war years. In general, during the war years, the population contributed 133 billion rubles to the state budget. rubles. This accounted for 11.9 percent of budget revenues. Thus, in the Soviet financial and tax system, the policy of collecting taxes for the state account was strictly enforced and served for the fair replenishment of the state budget [12. 299-300].

The nationwide socialist competition, which began in the republic's enterprises, collective farms and state farms, became an important means of increasing labor productivity and the production of military equipment and weapons. In the early years of the war, communist Saturdays and Sundays were in full swing to increase the defense fund. On June 18, 1941, the first Saturday was held in the republic. 1.2 million people took part in this Saturday and donated more than 3 million soums to the defense fund. At the same time, the collection of funds for the construction of a tank column named after the Komsomol of Uzbekistan began. More than 600,000 young people took part in the Sunday, October 12, 1941, who worked selflessly in factories and mills, cotton fields, and railways. Due to various fees collected from people and 2.5 
million soums were donated to the "Tank Column Construction Fund" [13.1985. 20.04].

During the war years, great care was taken of the families of those who went to the defense of the Motherland. If we look at the numbers, only in early 1943, 73.5 thousand pounds of grain, 10,000 head of sheep, 2,000 head of cattle were delivered to help the families on the front, and more than 850 houses were built and commissioned. The movement to create a national fund in the country had gained momentum. As mentioned above, during the war years, the contribution of Uzbek workers to the defense fund amounted to 650 million soums and $55 \mathrm{~kg}$ of gold and silver. In addition, 4.266 billion soums were paid from state fees and cash lotteries [14.37].

The material and financial support given to the front by the workers of the republic strengthened the armament of the combat units and raised the morale of the Soviet troops. The republic's agriculture supplied 4 million 806 thousand tons of cotton and fruit, 1 million 282 thousand tons of grain, 54.1 thousand tons of cocoons, 482 thousand tons of potatoes and vegetables, 57.6 thousand tons of fruit grapes, 36 thousand tons of husks, 159 thousand tons of meat, 22.3 thousand tons of wool during the war years [15. 451].

Historical research has shown that during the war years, for a number of objective and subjective reasons, the reconstruction of agriculture in the republic was extremely difficult. As a result of the reconstruction and reconstruction of all industrial enterprises in the country, the arrival of tractors and other agricultural machinery in our country had almost stopped. The supply of materials, fertilizers, and fuel for the repair of the collective and state farms had generally been reduced. Hundreds of thousands of rural workers were mobilized to the front, to the defense of the Motherland.

In the first days of the war, 30 million soums of money, bonds and valuables were collected from the families of the republic. During the war, the population of Uzbekistan contributed a total of 649.9 million soums cash and other precious metals to the defense fund. [16.227]. It can be seen that tank columns, aviation squadrons, armored trains were purchased and sent to the front at the expense of this fund, which was collected and formed from the people in difficult conditions.

Only in 1943, 2,100 aircraft, 2,318,000 air bombs, 17,100 mortars, 4,500 minesweepers, about 60,000 military-chemical equipment, 22 million mines and 560,000 shells, 1 million grenades, 3 million radio lamps for the field radio stations for the front were delivered from Uzbekistan. They also produced about 300,000 parachutes, 5 armored trains, 18 military medical trains, 2,200 mobile kitchens and 7,518.8 thousand soldier's blouse, 2,636.7 thousand cotton belts, and 2,861.5 thousand army boots [17. 268]. This was a great contribution of the people of Uzbekistan to the defeat and defeat of the Nazi invaders through various collections.

During the war years, the population spent 114.7 billion soums on war interests throughout the Union by paying various taxes, including various contributions and payments to the defense fund. 58.8 billion soums of them or $50.8 \%$ were military expenditures, the rest was spent on war needs behind the front lines [18.151]. These costs had been increased 
by reducing the cost of the national economy and socio-cultural activities.

If we take these figures at the level of Uzbekistan, the republican budget in 19411945 amounted to 786.5 million soums, $64.8 \%$ of economic expenditures, $21.8 \%$ of social and cultural activities, $9.8 \%$ of administrative expenditures. most of the social spending was also focused on defense needs. During the war, the share of revenues in the budget decreased as a result of increased military expenditures and declining revenues from state-owned enterprises. In order to rectify this shortcoming, incomes and agricultural taxes were increased in the first years of the war. Thus, the families of the missing soldiers who left Uzbekistan for the war during the war years suffered not only morally but also materially. The government raised the "Property Tax", "Agricultural Tax" and "Income Tax" rates to cover part of the military expenditures during the war years [19.86].

Most importantly, the main sources of budget revenues, along with taxes from citizens, funds from state reserve funds, funds from enterprises and other revenues, were government bonds and lotteries. This is evidenced by the fact that during the war years, 422.6 million soums were collected from these sources in the republican budget. In addition, during the war years, the Republic sent to the front 4 million 148 thousand tons of cotton and fruit, 54 thousand tons of cocoons, 3 million 83 thousand pieces of astrakhan leather and food products[9.86].

At the beginning of 1942, all the newspapers of the republic began to publish advertisements about the opening of the "current account" number 160676 in the city administration of the State Bank of the Commission for the Placement and Upbringing of Orphans and Orphans under the PCC of the UzSSR. All donations made by the government for the benefit of the children were requested to be transferred to this specified account. This call did not go unanswered. By March 1942, - 2 million 74 thousand soums were transferred to the account number 160676 . By 1943 , this fund amounted to 3.5 million soums [21. 456].

Of course, in such heroism shown by the people, women undoubtedly also contributed. In particular, the women of Uzbekistan showed real patriotism during the war. It is only in industry itself that the fruits of the great labor of so many women can be seen. For example, women workers at the Yangiyul Oil Refinery in Tashkent Region wrote in their resolution: "We want to go into production and replace our lands at all times in front of the machines. The commanders of the Red Army fighters are advancing to the front lines of the battlefield, and we are working selflessly behind the front lines, and here, too, we will accelerate the victory over the enemy "[22.506-507].

Hard-working Uzbek women drove machines, cars and tractors with all their might, picking cotton in the cotton fields with young children in their hands. The slogan "Everything for the front!" "Everything for victory" became a firm rule for the entire Soviet working class, all its detachments, including light and local industrial workers of Uzbekistan. The situation required the introduction of new technologies to produce new types of products for the front. For example, at the "Kizil tong" (Red Dawn) sewing factory, young men and 
women took the place of men who had gone to the front in the early days of the war, and at the end of 1941, 125 women successfully mastered the professions of electrician, locksmith and mechanic. A similar picture can be seen in other businesses. At the Tashkent shoe factory, dozens of female workers, who used to meet the norm of one and a half, had started to give two or three norms. " At the same time, the women also studied tasks they had not learned, did not know, were unfamiliar, and tried to fulfill the plan. For example, fulfilled the plan "motorist Maksimenka 143 percent, Mavshina 150-193 percent, Samina 150-170 percent, Abdurakimova 140-160 percent, Orifjonova 130-150 percent, Norkhojaeva 130-140 percent, Basheva 150-160 percent, Khazieva 150-160 percent [23. 506-507].

The material and financial support given to the front by the workers of the republic strengthened the armament of the combat units and raised the morale of the Soviet troops. The republic's agriculture during the war years supplied urgent 4 million 806 thousand tons of cotton and fruit, 1 million 282 thousand tons of grain, 54.1 thousand tons of cocoons, 482 thousand tons of potatoes and vegetables, 57.6 thousand tons fruit grapes, 36 thousand tons of husks, 159 thousand tons of meat, 22.3 thousand tons of wool for the front and victory. [24. 451].

Historical research has shown that during the war years, for a number of objective and subjective reasons, the reconstruction of agriculture in the republic was extremely difficult. As a result of the reconstruction and reconstruction of all industrial enterprises in the country, the arrival of tractors and other agricultural machinery in our country had almost stopped. The supply of materials, fertilizers, and fuel for the repair of the collective and state farms had generally been reduced. Hundreds of thousands of rural workers were mobilized to the front, to the defense of the Motherland.

However, the following figures show the significant contribution of the village workers of the republic to the export of livestock to the liberated areas: from 1943 the total amount of livestock sent was 182 thousand heads, and only until March 17, 1944 - 122 thousand 147 heads. In addition, by June 1, 1944, 176,148 head of livestock were purchased from the population and sent to the liberated areas. On December 22, 1939, the Central Committee of the All-Union Communist (Bolshevik) Party and the Soviet government adopted a resolution "On measures to further increase cotton production in Uzbekistan." The resolution set the task to increase the area under irrigated lands by 100,000 hectares, to increase the yield of cotton to 26 quintals per hectare instead of 17 quintals in 1939, and the amount of cotton grown from 16 million quintals to 26 million quintals. The struggle for an abundant cotton harvest intensified throughout the republic. In 1939, a movement of cotton growers began, who undertook to harvest $15,000 \mathrm{~kg}$ of cotton per season [25. 79] shows that before the war the agricultural population of the republic had set great goals for itself.

\section{CONCLUSIONS}

In general, the article confirms, first of all, that during the Second World War, the people of Uzbekistan and Uzbek families continued their way of life in the traditional way, with the 
heroism to work behind the scenes on the basis of their labor and humanity;

Secondly, like other nations, the Uzbeks contributed to the war defense fund, provided material assistance to the war. In such a difficult situation, due to the tolerant nature of the people, the people showed true international qualities. The cohesiveness of our national mentality has shown that it has been actively involved in mobilizing the population, organizing conscription, sending food, clothing, ammunition to the front, and accommodating the displaced.

Third, it can be seen that the rise of monopolybased bureaucracy, class hierarchy, and conservatism throughout the country during World War II also affected the form, nature, and functions of financial aid. That is, it confirmed that measures were taken to ensure the front, the military-industrial complex, mainly in accordance with the rules of the wartime defense fund. This, in turn, manifested itself later, that is, after the war, as a means of totalitarian command and control throughout the country.

\section{REFERENCES}

1. Oblomurodov N.X. Assistance to the workers of Uzbekistan in the restoration of the national economy and institutions. culture of the liberated regions of the USSR during the Great Patriotic War (19421945) (Based on the materials of the RSFSR, the Ukrainian SSR, the Byelorussian SSR. // Dissertation for the degree of candidate of historical sciences T., 1981. P 39-42.

2. High respect for the courage and memory of ancestors // Speech by President of the Republic of Uzbekistan Shavkat
Mirziyoyev at the solemn ceremony dedicated to the 75th anniversary of the Great Victory and the Day of Remembrance and Honor. // "Yangi O'zbekiston" newspaper. № 80. T., 2020. May 10.

3. High respect for the courage and memory of ancestors // Speech by President of the Republic of Uzbekistan Shavkat Mirziyoyev at the solemn ceremony dedicated to the 75th anniversary of the Great Victory and the Day of Remembrance and Honor. // "Yangi O'zbekiston" newspaper. № 80. T., 2020. May 10.

4. Tolipov F, Atamuratov M. Uzbek family: history and way of life. T., 2020. B 77-79

5. Po'latov I. Uzbekistan's contribution to the great victory. T., "Uzbekistan", 1974. B. 181.

6. Tolipov F, Atamuratov M. Uzbek family: history and way of life. T., 2020. B 77-79

7. Rajabova R.Yo, Karimov R.H and others History of Uzbekistan. (1917-1993 yy) T., 1993. Page 245

8. Rajabova R.Yo, Karimov R.H and others. History of Uzbekistan. (1917-1993 yy) -T., 1993. Page 245

9. Rajabova R.Yo, Karimov R.H and others. History of Uzbekistan. (1917-1993 yy) -T., 1993. Page 245

10. Rajabova R.Yo, Karimov R.H and others. History of Uzbekistan. (1917-1993 yy) -T., 1993. Page 245

11. Duschanov R. Taxes in the Soviet state during the Second World War and the procedures established in them.// Proceedings of the International Scientific Conference on Current Issues in the History of the Peoples of Central Asia. -T., 2020- B 299-300. 
12. Duschanov R. Taxes in the Soviet state during the Second World War and the procedures established in them.// Proceedings of the International Scientific Conference on Current Issues in the History of the Peoples of Central Asia. -T., 2020- B 299-300.

13. Soviet Uzbekistan. April 20, 1985

14. Oblomurodov N. Assistance of Uzbekistan to the regions affected by the Nazi attack.T., "Science". 1985. B 37.

15. Essays on the history of the Communist Party of Uzbekistan., 1974, p. 451

16. History and culture of Uzbekistan. (Edited by Sh. Karimov). T., 1993 p.222.

17. Oblomurodov N. Hazratkulov A, Tolipov F and others. History of Uzbekistan. T., 2011. $268 \mathrm{p}$.

18. Oblomurodov N, Tolipov F. History of taxes in Uzbekistan. T. 2009. Page 151

19. Directory on taxes and savings collection. M., 1973. S- 86.

20. Directory of taxes and savings collection. M., 1973. S- 86.

21. History of Uzbekistan. // Uzbekistan in the period of Soviet colonialism.T., 2000. 456 pages.

22. O'rolova $M$. The activities of Uzbek women behind the front lines. // Looking to the past. №2 special number. B 506507.

23. O'rolova M. The activities of Uzbek women behind the front lines. // Looking to the past. №2 special number. B 506-507

24. Essays on the history of the Communist Party of Uzbekistan., 1974, p. 451

25. Oblomurodov N. Assistance of Uzbekistan to the regions affected by the Nazi attack.T., "Science". 1985. p.79 